\title{
Analysis of Potential Micro hydro for Water Treatment Plant
}

\author{
Tri Suyono ${ }^{1}$, Lita Asyiriati Latif ${ }^{2}$ \\ Department of Mechanical Engineering \\ Universitas Khairun \\ Ternate, Indonesia \\ 1tri_suyono78@yahoo.com, ${ }^{1}$ lithalatif@yahoo.com
}

\begin{abstract}
The operation of the Water Treatment Plant (WTP) requires electrical energy to drive chemical systems, namely dossing pumps and chemical mixers and lighting lamps. In WTP, most of the gravity systems are located far from settlements and most of the access roads are quite difficult, and there is no electricity network available from PLN, whereas if using a machine, the supply and transportation of fuel oil is not easy, this gives result in the WTP that is being built only to function as a pre-sedimentation tank, so that the quality of water delivered to customers especially in the rainy season is still cloudy. This requires a solution to supply energy that is not fuel dependent, easy and inexpensive so that the price of water production also decreases with good water quality. The remaining press of water flowing from the intake to the WTP is above 3 bars on average, so it still has the potential to be used to generate electricity by installing micro-hydro, so that water energy before entering the WTP can generate electricity. The point is that water energy is used to produce electrical energy to process water itself (from water for water). The working principle of micro hydro is the same as micro hydro in general, but because the fast pipe used is the transmission pipe with the installation system not always straight and the average distance above $3 \mathrm{~km}$, it is necessary to do a hydraulic study to determine the micro-hydro capacity that will be installed. Installation of micro hydro in water treatment plants must have a minimum head of 30 meters (already reduced by head losses). Micro Hydro for WTP is designed with power capacity that is suitable for the needs of electrical energy in WTP, namely $3 \mathrm{~kW}, 5 \mathrm{~kW}, 7.5 \mathrm{~kW}$ and $10 \mathrm{~kW}, 12.5 \mathrm{~kW}, 30 \mathrm{~kW}, 50 \mathrm{~kW}$ and can be more if the results of technical calculations can produce more electricity than that. While the capacity of the WTP that can be installed micro hydro is between 5 litres / second - 200 / second, but it can also be used for capacities above 200 litres / second with specifications and special treatment. Based on the study review, it can be seen that the use of micro-hydro in water treatment systems is very appropriate in providing cheap and environmentally friendly energy to meet the electricity needs of WTP.
\end{abstract}

Keywords-Water Discharge; Capacity; Water Treatment; Energy; Micro Hydro

\section{INTRODUCTION}

The installation of drinking water supply systems that are built is quite a lot that uses a gravity system with a water discharge between $5 \mathrm{~L} / \mathrm{sec}(0.05 \mathrm{~m} 3 / \mathrm{sec})$ to $200 \mathrm{~L} / \mathrm{s}(0.1$ $\mathrm{m} 3 / \mathrm{sec}$ ) with a head difference between 35 up to 100 meters, and the length of the transmission pipe or pipeline is fast between 700 meters to 12,000 meters. From the description of the above conditions, there is potential for residual usage of water from the dam to the Water Treatment Plant (WTP) to drive a Micro Hydro Power Plant as a source of electrical energy for WTP needs and if possible for the surrounding community. For this reason, it is necessary to do hydraulic analysis on the transmission pipe to find out the remaining press of the water or the actual head after passing the transmission pipe at a certain distance. Micro Hydro for PAPs needs to be developed as an effort to ensure the operational continuity of PAPs that are often constrained by the costly and difficult supply of electricity. This Micro Hydro Development can be carried out throughout WTP especially for gravity systems and still allows for WTP pumping systems. MicroHydro Installation on WTP can also have double functions because in addition to generate electricity can also have functioned as a mixer or chemical mixer at the time of affixing. Electrical energy requirements for the chemical system and lighting systems and other supporting equipment ranging from $3 \mathrm{~kW}$ to $15 \mathrm{~kW}$, depending on capacity and WTP system built.

Currently, there are more than 25 WTP in Indonesia that use micro-hydro, with the highest distribution in North Maluku province, which is around 19 units, some in North Sulawesi, Central Sulawesi, North Sumatra, Jambi and West Sumatra. Hydro-micro installed in WTP has proven to be quite effective in the provision of drinking water, because managers are not burdened with the cost of providing energy that is quite expensive and difficult in some locations and with the installation of micro-hydro in the WTP is also able to maintain the operational continuity of the WTP so that the quality of water is maintained well.

\section{BENEFITS}

Micro-hydro as a simple environmentally friendly energy source that does not need to change the IPA structure is very suitable as a provider of electrical energy for chemical pumps, lighting other purposes. Even for locations that are far from settlements and there is no electricity available, PLN can 
become a central source of communication energy (handphone changer) so that the IPA location is more alive with more people coming in. Of course, with a record, it does not interfere with the operation of the IPA. So that the IPA for the SPAM gravity system is really zero fuel, and for the pumping system it can do $40 \%$ energy efficiency.

\section{LITERATURE REVIEW}

\section{A. Micro-hydro}

Micro-hydro or what is meant by Micro Hydro Power Plant is a power plant that uses hydropower as its driving force, such as irrigation canals, rivers or natural waterfalls by utilizing the head height and the amount of water discharge. Hydro micro is a term that consists of micro words which mean small and hydro which means water.

Hydro-micro is a small-scale hydroelectric power plant (PLTA) with a capacity limit of $5 \mathrm{~kW}$ (Kilo Watt) - $1 \mathrm{MW}$ (MegaWatt) per unit (ESDM Research and Development Agency, 2012). There are several other power restrictions for the category of Hydro Micro besides those stated by the ESDM Research and Development Agency, namely a maximum capacity of $120 \mathrm{~kW}$ and less than $200 \mathrm{~kW}$ (Damastuti, A.P., 1997). There are also other classifications that sort out a small-scale hydropower system into three, namely mini hydro with capacities between $100 \mathrm{~kW}$ to $1 \mathrm{MW}$, micro-hydro with capacities between $1-100 \mathrm{~kW}$, and pico hydro with capacities from several Watts (W) to 1,000 Watts.

\section{B. The working principle of micro hydro}

Micro Hydro Power Plants (MICRO HYDRO) in principle make use of the height difference (head) and the amount of water discharge in the irrigation channel water flow, river or waterfall. This water flow will rotate the turbine shaft to produce mechanical energy. This energy then moves the generator and generates electricity [1].

The development of Micro Hydro needs to be initiated by the construction of a dam to regulate the flow of water that will be used as a driving force for Micro Hydro [2]. This dam can be a concrete dam or an oval dam. Dams need to be equipped with sluice gates and garbage filters to prevent the entry of dirt or silt. Dams should be built on a stable and safe riverbed against flooding.

Near the dam, the intake building is built. Then proceed with the making of settling basin which serves to settle sand and filter dirt so that the water entering the turbine is relatively clean. After that, the head-race is built which functions to drain water from the intake. This channel is equipped with an overflow channel at any given distance to remove excess water. This channel can be either open or closed channel.

Soaking tub (forebay) is also built to calm the flow of water and prevent water turbulence before being deployed to a fast pipe (stacker). This channel is made with concrete construction and is as close as possible to the turbine house to save fast pipes.
Rapid PIPA functions to drain water before entering the turbine. In this pipe, the potential energy of water in the settling tank is converted into kinetic energy which will rotate the turbine wheel. Usually made of steel pipes that are pulverized, then welded [3]. Flanges are used for connection between pipes. This PIPA must be supported by a foundation that is able to withstand static and dynamic loads. These foundations and stands are kept as straight as possible because it needs to be designed in accordance with soil conditions.

After leaving the pipe rapidly, the water will enter the turbine in the inlet. Inside is a guided vane to regulate the opening and closing of the turbine and regulate the amount of water that enters the runner blade or blade (the main component of the turbine) [4]. Runners are made of high tensile strength steel which is welded on two parallel plates. Water flow will rotate the runner and produce kinetic energy that will rotate the turbine shaft.

The energy arising from the rotation of the shaft is then transmitted to the generator. All of these systems must be balanced. The turbine needs to be equipped with a casing that functions to direct the water to the runner. At the bottom of the casing, there is a locking turbine. Bearings are located on the left and right of the shaft and serve to support the shaft so that it can rotate smoothly.

Turbines, generators and control systems are each placed in a separate house. The foundation of the turbine-generator must also be separated from the foundation of this house. The goal is to avoid problems due to vibration. Turbine houses must be designed so as to facilitate maintenance and inspection [5].

The first opinion expressed by Pudjanarsa stated that water turbines are broad, while the opinions of both expressed specifically about the workings of hydraulic turbines, for the third statement is more specific by dividing the working principle of impulses and reactions.

\section{Turbine generates power}

From the Q water capacity and high falling water, the turbine output power is obtained. Turbine output power is calculated using the equation:

Where:

$$
P_{a}=Q \rho g H
$$

$\mathrm{Pa}=$ water power $(\mathrm{kW})$

$\mathrm{Q}=$ Water capacity $(\mathrm{m} 3 / \mathrm{s})$

$\rho=$ Mass of water type $(\mathrm{kg} / \mathrm{m} 3)$

$\mathrm{g}=$ Gravity force $(\mathrm{m} / \mathrm{s} 2)$

$\mathrm{H}=\mathrm{Head} /$ waterfall (m)

and turbine efficiency:

$$
\eta_{t}=\frac{P_{t}}{P_{a}}
$$

Then the turbine power is obtained:

$$
\begin{aligned}
& P_{t}=\eta_{t} P_{a} \\
& P_{t}=Q \rho g H \eta_{t}
\end{aligned}
$$


Generator power calculation:

Where:

$\mathrm{Pt}=$ Power turbine $(\mathrm{kW})$

$\eta \mathrm{t}=$ Turbine efficiency

In simple terms, it can be stated that the higher the falling water, with the same flow capacity, will have greater potential energy compared to the lower waterfall.

In the analysis and calculation phase the data use the following formulas:

1. Calculation of flow velocity

2. The Reynolds number calculation

$$
R_{e}=\frac{V D \rho}{\mu}=\frac{V D}{v}
$$

3. Calculation of major losses

$$
H_{f}=f \frac{L v^{2}}{2 D g}(m)
$$

4. Calculation of minor losses

$$
H_{f m}=K \frac{V^{2}}{2 g}
$$

5. Calculation of total net head

$$
H_{\text {net }}=H_{\text {gross }}-\operatorname{losses}(m)
$$

\section{PRINCIPLES OF HYDRO MICRO WORKING FOR PAPERS}

The working method of micro hydro for PAP is in principle the same as micro hydro in general, only the type and installation system are slightly different. The way micro hydro works for WTP is as follows:

1. Water from a water source through a fast transmission pipe into the turbine is inserted into the turbine water then the water that has passed through the water turbine is channelled to the tank $\mathrm{V}$ not, so that the WTP will function as usual without any changes in structure or system, only need to strengthen tank $\mathrm{V}$ construction just note the microhydro is installed on top of the tank $\mathrm{V}$ note. As shown in Figure 1.

2. The micro-hydro location can be done on top of the V note tank or at the bottom separated from the WTP building and given a protective building (microhydro house).

3. The electricity produced is electricity that has been adjusted to the electricity needs for chemical pumps and other purposes. The electricity produced will be the same as the WTP operating hours or as long as the water flows, so the electricity supply will be continuous and able to meet the needs.

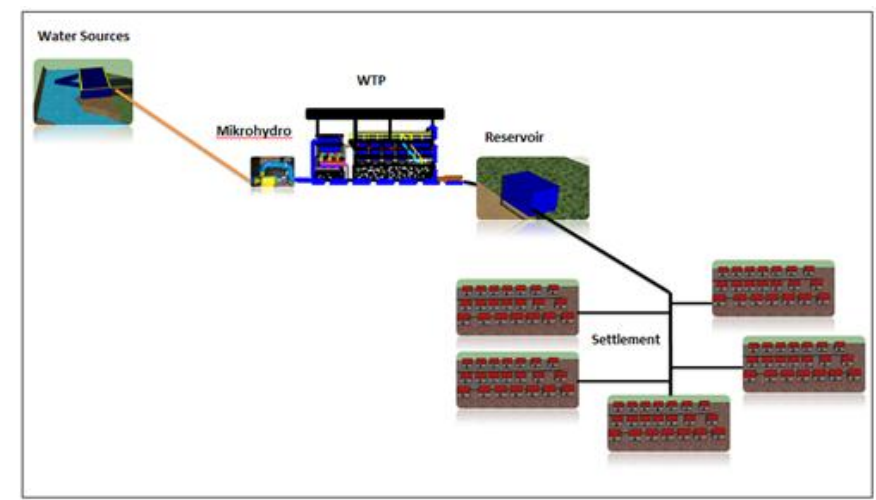

Fig. 1. Scheme of Micro Hydro Working Principles for WTP

\section{STUDY}

A. Theoretical and experimental studies (Theory study of the effect of discharge $(Q)$ on output power $(P))$

The graph of the effect of discharge $(\mathrm{Q})$ on power $(\mathrm{P})$ on the calculated data explains that the greater the water discharge the greater the power produced. This can be seen in Figure 5 where the discharge $(0.01) \mathrm{m}^{3} / \mathrm{s}$ of power produced is $(5.02) \mathrm{kW}$, the discharge $(0.0125) \mathrm{m}^{3} / \mathrm{s}$ of the generated power is $(6.15) \mathrm{kW}$, discharge $(0.015) \mathrm{m}^{3} / \mathrm{s}$ of generated power is (7.19) $\mathrm{kW}$, discharge $(0.0175) \mathrm{m}^{3} / \mathrm{s}$ of generated power is $(8.13) \mathrm{kW}$, and at discharge $(0.02) \mathrm{m}^{3} / \mathrm{s}$ the power produced amounting to (8.97) $\mathrm{kW}$.

\section{B. Experimental results}

Graph of the effect of discharge $(\mathrm{Q})$ on power $(\mathrm{P})$ on the research data explains that the greater the water discharge the greater the power produced. This can be seen in Figure 6 where the discharge $(0.01) \mathrm{m}^{3} / \mathrm{s}$ of power is at $(4.80) \mathrm{kW}$, the debit is increased to $(0.0125) \mathrm{m}^{3} / \mathrm{s}$ the power goes up to $(5.90)$ $\mathrm{kW}$, then the discharge is increased to $(0.015) \mathrm{m}^{3} / \mathrm{s}$ the power also rises to $(7.08) \mathrm{kW}$, then the debit is increased again to $(0.0175) \mathrm{m}^{3} / \mathrm{s}$ the power goes up to $(8.12) \mathrm{kW}$, until the discharge $(0,02) \mathrm{m}^{3} / \mathrm{s}$ power also rises to $(8.94) \mathrm{kW}$.

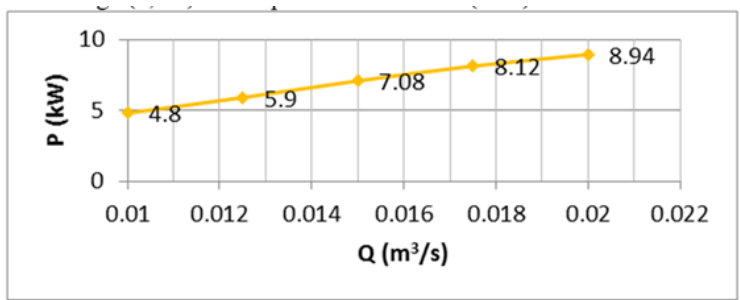

Fig. 2. Graph of the effect of discharge (Q) on power (P) on the data calculated from experimental data

\section{Comparison between data from theoretical calculations and test or experimental results}

Comparison of the effect of discharge (Q) on power (P) between theoretically calculated data with the results of calculation of experimental results can be seen in Figure 2. It is known that the results of calculations have a higher value than the research data but not too far. This illustrates that the 
efficiency of turbines in micro-hydro systems is quite high, or close to theoretical efficiency.

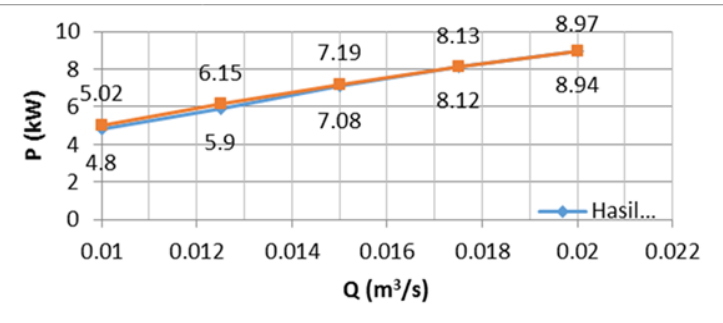

Fig. 3. Comparison graph of the effect of discharge $(\mathrm{Q})$ on the power $(\mathrm{P})$ between the results of the research data and the calculation data

\section{Effect of discharge $(Q)$ on total efficiency $(\eta T)$ on experimental data}

Graph of the effect of discharge (Q) on total efficiency $(\eta T)$ in the research data explains that the greater the water debit the total efficiency tends to increase. This can be seen in Figure 8 where the discharge $(0.01) \mathrm{m}^{3} / \mathrm{s}$ total efficiency (0.727), discharge $(0.0125) \mathrm{m}^{3} / \mathrm{s}$ total efficiency rose to $(0.729)$, discharge $(0.015) \mathrm{m}^{3} / \mathrm{s}$ total efficiency rose again become $(0.748)$, debit $(0.0175) \mathrm{m}^{3} / \mathrm{s}$ total efficiency increases to $(0.759)$, but at discharge $(0.02) \mathrm{m}^{3} / \mathrm{s}$ the total efficiency drops slightly to (0.758).

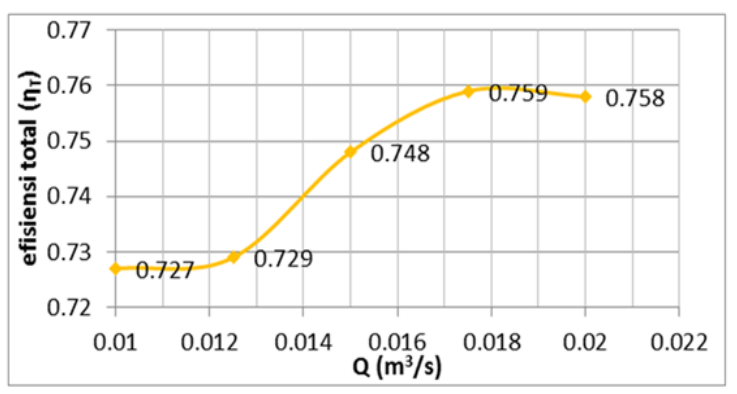

Fig. 4. Graph of the effect of discharge (Q) on total efficiency ( $\eta \mathrm{T})$ on research data

\section{E. Installation system and selection of micro hydro}

The selection of micro hydro that will be installed must pay attention to a number of matters for consideration, namely:

a. Electric power needs

TABLE I.

SELECTION OF MICRO HYDRO AND ITS EFFECT ON OUTPUT WATER DISCHARGE

\begin{tabular}{|c|c|c|c|c|c|c|c|c|c|c|c|c|}
\hline $\begin{array}{c}\text { Head } \\
(\mathbf{m})\end{array}$ & $\begin{array}{c}\text { Q Water } \\
\text { in } \\
\text { (L/DET) }\end{array}$ & $\begin{array}{c}\text { Q Water } \\
\text { out } \\
\text { (L/DET) }\end{array}$ & $\begin{array}{c}\text { Daya } \\
\text { MH } \\
(\mathrm{KW})\end{array}$ & $\begin{array}{c}\text { Q Water } \\
\text { in } \\
\text { (L/DET) }\end{array}$ & $\begin{array}{c}\text { Q Water } \\
\text { out } \\
\text { (L/DET) }\end{array}$ & $\begin{array}{c}\text { Daya } \\
\text { MH } \\
(\mathbf{K W})\end{array}$ & $\begin{array}{c}\text { Q Water } \\
\text { in } \\
(\mathrm{L} / \mathrm{DET})\end{array}$ & $\begin{array}{c}\text { Q Water } \\
\text { out } \\
\text { (L/DET) }\end{array}$ & $\begin{array}{c}\text { Daya } \\
\text { MH } \\
\text { (KW) }\end{array}$ & $\begin{array}{c}\text { Q Water } \\
\text { in } \\
\text { (L/DET) }\end{array}$ & $\begin{array}{c}\text { Q Water } \\
\text { out } \\
\text { (L/DET) }\end{array}$ & $\begin{array}{c}\text { Daya } \\
\text { MH } \\
(\mathrm{KW}) \\
\end{array}$ \\
\hline 20 & 20 & 10.4 & 3.3 & 30 & 15.6 & 5.0 & 50 & 29 & 8.3 & 90 & 48 & 13.3 \\
\hline 25 & 20 & 11.6 & 4.2 & 30 & 16.8 & 6.3 & 50 & 31 & 10.4 & 90 & 51.2 & 16.7 \\
\hline 30 & 20 & 12.2 & 5.0 & 30 & 17.4 & 7.5 & 50 & 32 & 12.5 & 90 & 52.8 & 20.0 \\
\hline 35 & 20 & 12.6 & 5.8 & 30 & 18.3 & 8.8 & 50 & 33 & 14.6 & 90 & 54.4 & 23.3 \\
\hline 40 & 20 & 13.2 & 6.7 & 30 & 19.2 & 10.0 & 50 & 34 & 16.7 & 90 & 57.6 & 26.7 \\
\hline 45 & 20 & 13.7 & 7.5 & 30 & 20.4 & 11.3 & 50 & 35 & 18.8 & 90 & 60.8 & 30.0 \\
\hline 50 & 20 & 14.6 & 8.3 & 30 & 21.3 & 12.5 & 50 & 37 & 20.8 & 90 & 62.4 & 33.4 \\
\hline 55 & 20 & 14.9 & 9.2 & 30 & 22.5 & 13.8 & 50 & 38 & 22.9 & 90 & 63.6 & 36.7 \\
\hline 60 & 20 & 15.6 & 10.0 & 30 & 23.4 & 15.0 & 50 & 39.5 & 25.0 & 90 & 65.6 & 40.0 \\
\hline 65 & 20 & 16.2 & 10.8 & 30 & 24.3 & 16.3 & 50 & 41 & 27.1 & 90 & 67.6 & 43.4 \\
\hline
\end{tabular}

b. WTP capacity

c. Head (height difference between press release (BPT) and height of WTP Micro Hydro.

In principle, the location of the Micro Hydro installation at the Water Treatment Plant (WTP) is adjusted to the field conditions and some technical and non-technical considerations (aesthetics etc.), can be above the WTP or made separate buildings outside the structure of the WTP building, but of course each installation system will have an effect on the output power produced by Micro Hydro. Some examples of micro hydro installation can be seen in Figures 9, 10 and 11.

How to choose micro hydro power can use the following calculation example:

If the water source is at an elevation of 92 meter a.s.l. height at V note WTP 54 meter a.s.l. distance of $2.4 \mathrm{~km}$, with estimated head loss of 8 meters, the remaining head is:

$$
\mathrm{H}=92 \mathrm{~m}-(54+8 \mathrm{~m})=30 \text { meters }
$$

and if the debit / inlet water capacity is 40 liters / second = $0.04 \mathrm{~m} 3 / \mathrm{sec}$, then:

$$
\begin{aligned}
\mathrm{P} & =0.04 \times 30 \times 9.81 \times 0.85 \\
& =10 \mathrm{~kW}
\end{aligned}
$$

\section{F. Effect of micro hydro installation on output discharge at WTP}

Micro Hydro Installation at the end of the WTP inlet pipe will affect the discharge (Q) output coming out of the micro hydro caused by the resistance of the runner blade where Efficiency Ratio ( $\eta \mathrm{r}$ ) discharges in-out to and from the turbine between $0.52-0.925$, then $\mathrm{Q}$ out $=(\mathrm{Q}$ in $\mathrm{x} \eta \mathrm{r})$ whose value depends on the head, if the head is higher than the efficiency ratio will be higher. As a reference for selecting Hydro Micro for Water Treatment Plant (WTP) and its effect on output discharge can be seen in table 2 . d. The model or type of WTP that will be installed with 


\begin{tabular}{|c|c|c|c|c|c|c|c|c|c|c|c|c|}
\hline $\begin{array}{c}\text { Head } \\
(\mathbf{m})\end{array}$ & $\begin{array}{l}\text { Q Water } \\
\text { in } \\
(\mathrm{L} / \mathrm{DET})\end{array}$ & $\begin{array}{c}\text { Q Water } \\
\text { out } \\
\text { (L/DET) }\end{array}$ & $\begin{array}{c}\text { Daya } \\
\text { MH } \\
(\mathbf{K W})\end{array}$ & $\begin{array}{c}\text { Q Water } \\
\text { in } \\
\text { (L/DET) }\end{array}$ & $\begin{array}{c}\text { Q Water } \\
\text { out } \\
\text { (L/DET) }\end{array}$ & $\begin{array}{c}\text { Daya } \\
\text { MH } \\
(\mathbf{K W})\end{array}$ & $\begin{array}{c}\text { Q Water } \\
\text { in } \\
\text { (L/DET) }\end{array}$ & $\begin{array}{c}\text { Q Water } \\
\text { out } \\
\text { (L/DET) }\end{array}$ & $\begin{array}{c}\text { Daya } \\
\text { MH } \\
(\mathbf{K W})\end{array}$ & $\begin{array}{c}\text { Q Water } \\
\text { in } \\
(\mathrm{L} / \mathrm{DET})\end{array}$ & $\begin{array}{c}\text { Q Water } \\
\text { out } \\
\text { (L/DET) }\end{array}$ & $\begin{array}{c}\text { Daya } \\
\text { MH } \\
(\mathrm{KW}) \\
\end{array}$ \\
\hline 70 & 20 & 16.6 & 11.7 & 30 & 24.9 & 17.5 & 50 & 42.5 & 29.2 & 90 & 70.4 & 46.7 \\
\hline 75 & 20 & 16.9 & 12.5 & 30 & 25.5 & 18.8 & 50 & 44 & 31.3 & 90 & 72.8 & 50.0 \\
\hline 80 & 20 & 17.6 & 13.3 & 30 & 25.8 & 20.0 & 50 & 45.5 & 33.4 & 90 & 74 & 53.4 \\
\hline
\end{tabular}

\section{CONCLUSION AND RECOMMENDATION}

\section{A. Conclusion}

Paying attention to the results of the study and testing it can be concluded that:

a. Micro Hydro Installation in a water treatment plant (WTP) is very effective to meet the electrical energy needs of the WTP, most of which are far from settlements and access to the PLN electricity network, even some of which do not have an adequate access road to transport fuel oil. Electricity needs in WTP are for chemical systems, lighting systems or other supporting equipment. This technology is suitable to be developed to optimize the operation of WTP, especially those with gravity flowing systems, so that it does not require additional operational costs to produce water.

b. Micro-hydropower capacity for WTP between $3 \mathrm{~kW}$ up to $50 \mathrm{~kW}$ and can be more for large capacity (above 100 liters/second) with a higher head (above 70 meters).

c. The selection of Micro Hydro must consider the level of energy requirements, WTP capacity, height difference and also the type of WTP that will be installed Micro Hydro, so the installation of Micro Hydro is truly effective and does not interfere with the WTP working system. d. The installed Micro Hydro must have residual press after passing through the Turbine or Balde runner, making it possible to install it in the desired part both below and above on all WTP models or types.

e. The research data shows that the greater the water debit, the greater the total efficiency obtained. In one study sample, it was found that with water discharge $(\mathrm{Q})=(0.01-0.02) \mathrm{m} 3 / \mathrm{s}$, the total efficiency $(\eta \mathrm{T})$ obtained was (0.727 - 0.759).

f. The water output capacity of micro hydro is very much determined by the difference in height or head, pipe diameter and length of the transmission pipe or fast pipe, the efficiency of the Ratio discharge in-out to and from the turbine between $0.52-0.925$.

\section{REFERENCES}

[1] A.P. Damastuti, Teknologi: Pembangkit Listrik Tenaga Mikrohidro, Wacana, Vol. 8, 1997.

[2] Y.S.H.N. Hunggul, M. K. Sallata, Mikro Hidro, Pembangkit Listrik Tenaga Mikro Hidro, Yogyakarta: Andi, 2015.

[3] PT. Kusuma Wardana Group. Buku Panduan Instalasi, Operasi dan Pemeliharaan Mikro Hidro (Radial-Flow Hydroelectric Generator). Surabaya, 2016.

[4] A. Pudjanarsa, D. Nursuhud, Mesin Konversi Energi. Yogyakarta: Andi, 2006.

[5] K. Umar, Penuntun Praktikum Fenomena Dasar Mesin. Universitas Khairun, Ternate, 2012. 